\title{
Size Reduction by Grinding as an Important Stage in Recycling
}

\author{
Marek Macko \\ Casimir the Great University in Bydgoszcz \\ Poland
}

\section{Introduction}

Today, the issue of size reduction methods are one of the important fields of research as regards processing and recycling problems as growing post-use waste volume is becoming more widespread. This concerns, among others, polymer materials. The annual volume of polymer materials manufactured all over the world reaches nearly 260 million $\mathrm{Mg}$, out of which about 60 million $\mathrm{Mg}$ in Europe [18]. Taking into account short life (which particularly applies to packages), necessity to meet requirements of the sustainable development policy as well as criteria of environmental procedures being implemented (e.g. LCA), effective management of that waste shall have significant consequences in the near future. There are many waste management methods, among which material or energy oriented recycling are particularly interesting $[5,29]$. Comminution (grinding) is the process of key importance in every scenario. It can be assumed that energy potential of polymer materials (recyclates) shall be of increasing importance as new clean technologies of waste incineration and energy utilization are implemented. Analysts estimate that up to $20 \%$ of the global plastic production is subject to recycling in the first place, due to poor quality of a product, and $100 \%$ of it is recycled by comminution after use [45]. Due to visco-elastic properties of the materials subject to grinding and as the grinding machines are usually of general-purpose, grinding is a relatively energy consuming process. The power demand for grinding generally amounts to $(20 \div 500) \mathrm{kW} \cdot \mathrm{h} / \mathrm{Mg}$, which makes $25 \div 50 \%$ of the total electric power needed for material processing $[13,45]$. It is estimated that up to $8 \%$ of the global power demand is allocated for comminution, granulation and agglomeration, while in case of minerals processing, even up to $70 \%$ of the total power is used for comminution [19]. Currently a lot of attention is paid to the efficiency of grinding, particularly as regards relationship between efficiency of machine grinding and size reduction of separate grain (as

\begin{tabular}{|l|r|}
\hline Grinder type & Efficiency \\
\hline Multi-edge cutting mill & $25 \div 40 \%$ \\
\hline Beater mills & $17 \div 25 \%$ \\
\hline Roller mills & $7 \div 15 \%$ \\
\hline Ball mills & $6 \div 9 \%$ \\
\hline Jet mills & $1 \div 2 \%$ \\
\hline
\end{tabular}

Table 1. Range of achieved efficiency for selected grinders 
a relationship of power demand between physical and model conditions). Table 1 shows estimated efficiency values of selected design solutions. The range of grinding application can also be relatively broad depending on the expected grain size level for different materials and power demand range (fig. 1).

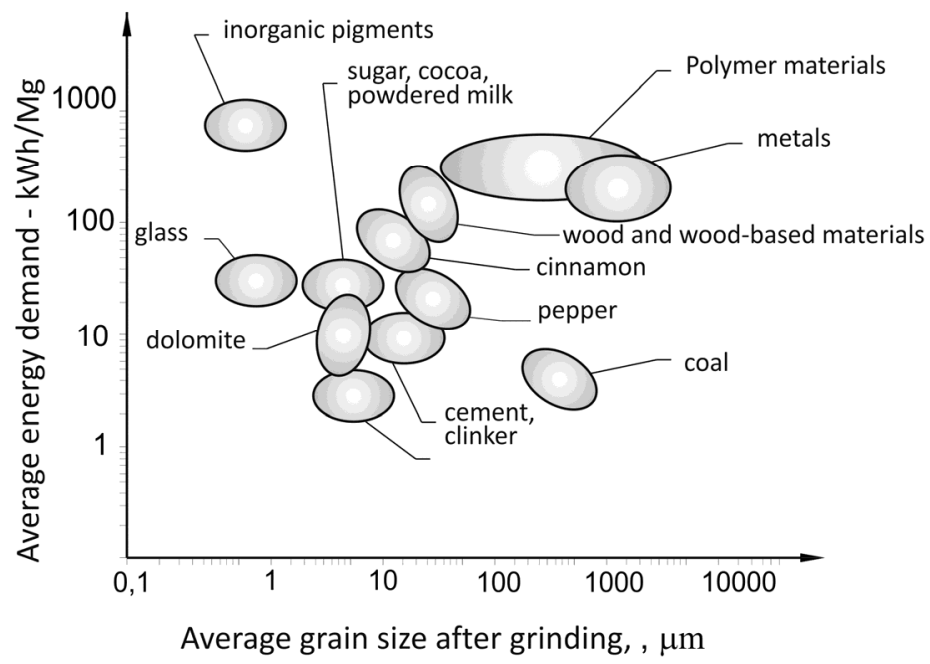

Fig. 1. Range of energy-related and dimensional requirements for wide spectrum of materials (based on studies by M. Pahl [35], J. Sidor [43], W. Peukert [36], J. Flizikowski [13], G. Schubert [42], V. Reppelin [39] and others)

The process efficiency issue is associated with the parameter of the unit energy consumption as the measure of energy needed to grind $1 \mathrm{~kg}$ of plastic. Energy demand for rough and medium grinding is $20 \mathrm{~kW} \cdot \mathrm{h} / \mathrm{Mg} \div 130 \mathrm{~kW} \cdot \mathrm{h} / \mathrm{Mg}$, while for very fine grinding it reaches even $800 \mathrm{~kW} \cdot \mathrm{h} / \mathrm{Mg}$ (for currently used solutions).

\section{The state of the art: New and previous design solutions of comminution systems for non-brittle recycles new and former design solutions of comminution systems for non-brittle recyclates}

The basic comminution methods (also known as mechanical or phenomenological models), are usually based on three main load types, i.e.: compression, tension and shear. Depending on physical properties, strength properties and the type of the material subject to grinding, to ensure high efficiency of the process, adequate reduction of shape and size of the input material must be used in the design stage.

According to H. Rumpf [40] and M.H. Pahl [34], there are four types of the grinding process used to produce elementary particles of the expected size and shape. They were briefly described and explained in fig. 2.

In case of polymer materials and cross-linked elastomers, the prevailing part in the grinding process is played by shearing (cutting) between two edges (marked in fig. 2 as grinding type I). This type of cutting is known as so-called "quasi-technological" cutting and it is used in, 
for example, multi-edge grinders characterized by low energy consumption, low noise level and good repeatability of grain classes [4, 13].

Cutting between two cutting edges is widely used in cutting mills, in particular for grinding of plastics and cross-linked elastomers [48, 3].

I. Type of load applied to a particle between two surfaces

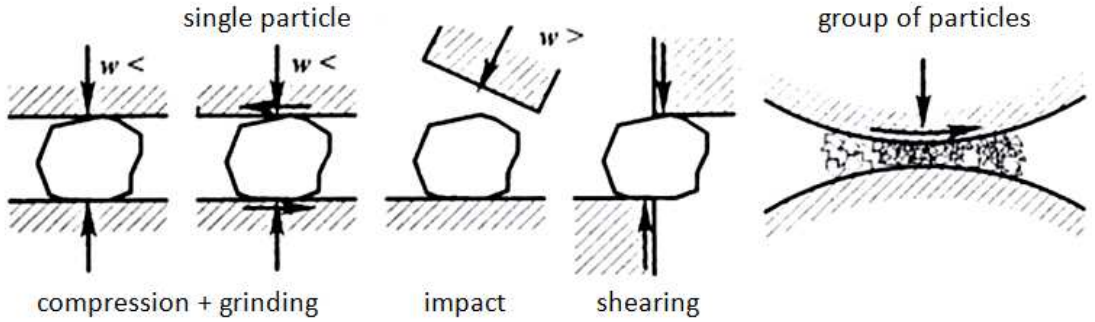

II. Type of load applied to a particle with one surface (w>>)

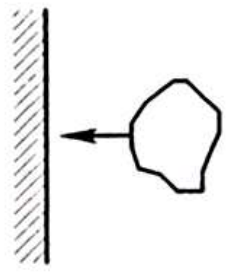

impact against the wall

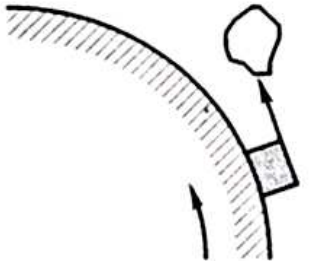

impact against an oppoșite rotary tool

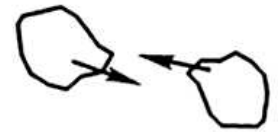

disintegration by collision of two particles

III. Load applied to a particle by the surrounding environment

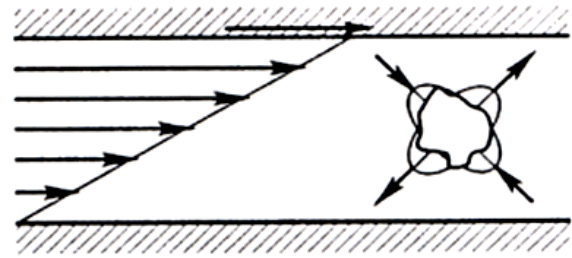

explosion

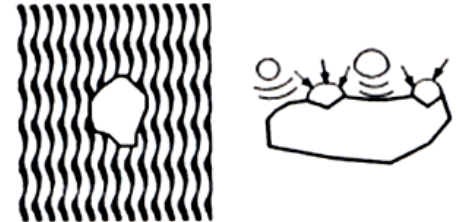

wave pressure

IV. Monitoring of the grinding using non-mechanical factors

\section{Electro technical \\ Chemical interference}

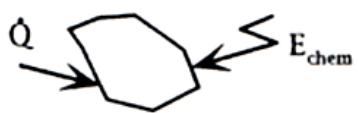

Fig. 2. Mechanical (fenomenological) models of grinding according to H. Rumph and M.H. Pahl $[35,40]$ 
According to K. Höffl, comminution can be effected by two main division types only: breaking and shearing [17]. This is due to the increase of the distance between the particles caused by normal and shear stresses. However, main decohesion types are most often analysed based on the shear cutting theory (fig. 3) [9, 10, 13]:

- exclusively under the influence of normal force N, without lateral displacement of the tool (cutter) and without the impact of the lateral force; the slide cutting angle $\tau=0$, (collisions); cutting is of dynamic nature (chopping),

- $\quad$ under the influence of the normal force $\mathrm{N}$, and simultaneous influence of the lateral (tangent) force $\mathrm{T}$ without the slip; as the tool operation angle (slip cutting) is smaller than the friction angle $\tau<\varphi$, the tool (cutter) movement causes lateral displacement of the plastic particles being cut so that, as a result, cutting process takes place under influence of the normal force (beater-and-shear type),

- $\quad$ under the influence of the normal force $\mathrm{N}$ and the lateral force $\mathrm{T}$, including the slide; the slide cutting angle is higher than the friction angle $\tau>\varphi$, so the friction resistance between the cutting edge and object being cut is smaller than the lateral component, which causes the cutter slide with reference to the material layer and thus it facilitates material cutting (shear cutting).

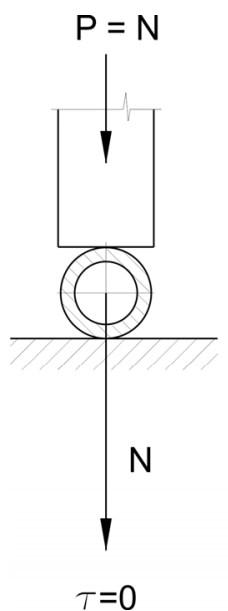

(a)

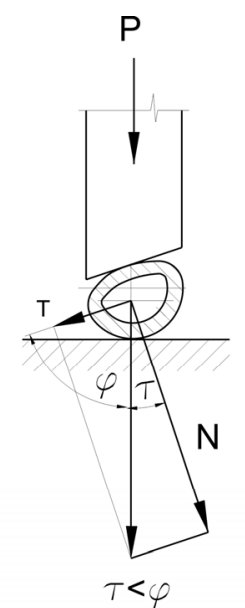

(b)

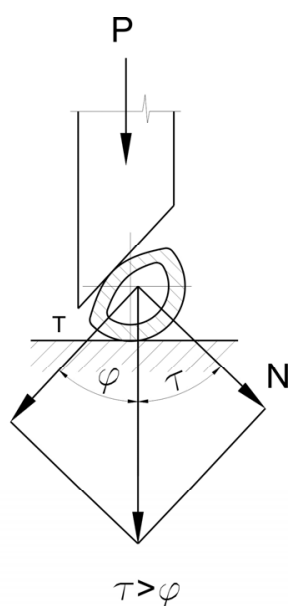

(c)

Fig. 3. Cutting types: a) cutting under the influence of the normal force only - beater type, b) cutting also under the influence of the lateral component, without the slide, c) cutting also under the influence of the lateral component, with the slide

Material and energy oriented recycling of relatively large parts (e.g. boxes, barrels) is performed in two stages. The first stage usually includes processing in roller and beater mills and then products are further ground (which is usually called as re-granulation) in order to obtain the form of the plastic that allows re-use. The main group of machines used at that stage includes granulators - cutting mills [13].

Current technical knowledge includes studies on grinding of selected materials using specific group of grinders. Polymer materials are ground using grinders of different design 
solutions. Some of them have been adapted to other fields of industry, e.g. agricultural engineering [9]. In the author's opinion, the most numerous group among polymer material grinding machines are beater and cutting grinders characterised by very diverse shape of the working space (fig. 4.).

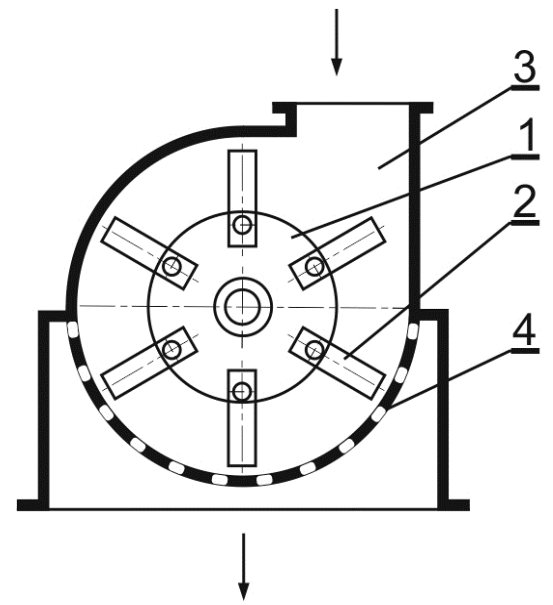

(a)

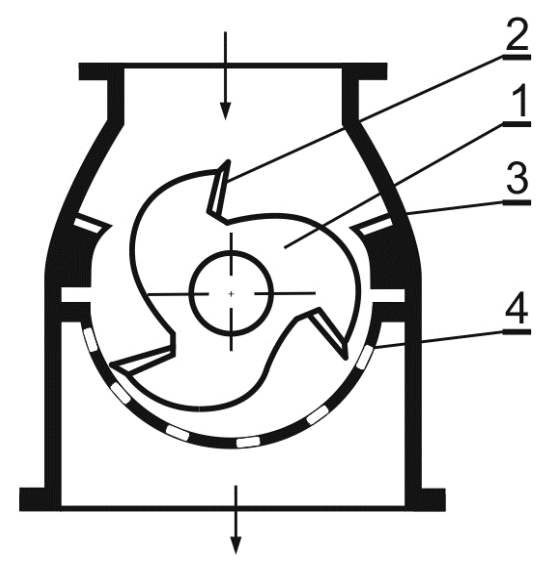

(b)

Fig. 4. Sample design solutions: a) beater mill: 1-rotor, 2-beater, 3-hopper, 4-screen, b) cutting mill: 1-rotor, 2-cutter, 3-counter-cutter, 4-screen.

The following types of grinders and mills described in the literature are currently designed and manufactured based on available theories and patents: beater mills, cutting mills, hyperboloidal mills, chopper mills, quasi-cutting mills, disk mills, roller mills and special (ball mills, vibration mills, rotary-and-vibration mills, rolling mills) and other design solutions developed as the modification of the above mentioned ones. One can distinguish main ways of load application in those solutions (strain, torque, bending, cutting, squeezing, breaking, grinding), but all those processes usually occur together where one of them is the prevailing process, depending on the mill design.

Cutting mills with cutters spaced over the drum circumference are widely used for rough and medium grinding of, among others, non-ferromagnetic light metals, polymer material waste, tyres and papers waste [46].

Cutting mills belonging to the group called „block knife shears" are equipped with several cuboidal cutters. Due to high durability of the components and heavy weight of the flywheel (fig. 5) those mills are capable of grinding thick-walled polymer and metal parts (e.g. of electric motors and transformers) at the speed of $5 \div 20 \mathrm{~m} / \mathrm{s}$.

Different design solutions include many components that intensify grinding process, such as, fixed cutters, rotating cutters or screens with specially shaped rebounding surface. Figure no. 6. shows the design of the mill manufactured by Alpine [35] company, equipped with rotating cutters fastened over the drum and two fixed cutters including bumping blocks fastened to the housing, where the process can be controlled by screwing in (letting in) the parts towards the chamber of the mill. 


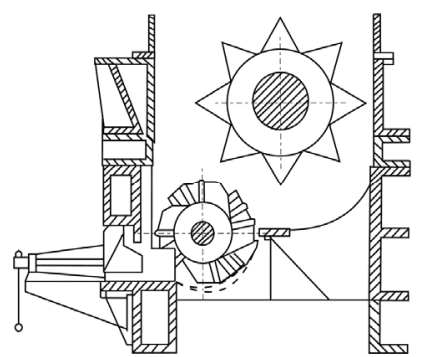

(a)

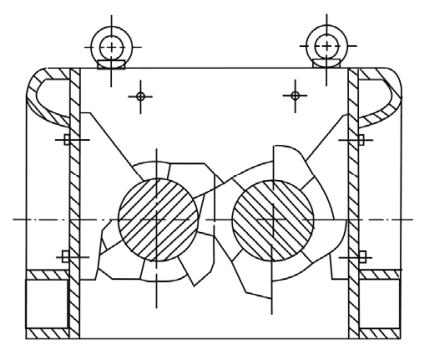

(b)

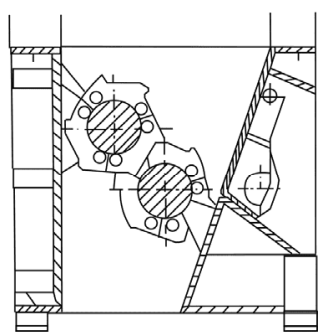

(c)

Fig. 5. Selected design solutions of mills equipped with double disk and roller systems:

a) single-rotor system with angle gap (Alpine/Germany) [32], b) double-rotor system with radial gap (Hoger/Germany) [30], c) four-rotor system with the angle gap (SID/Switzerland) [31]

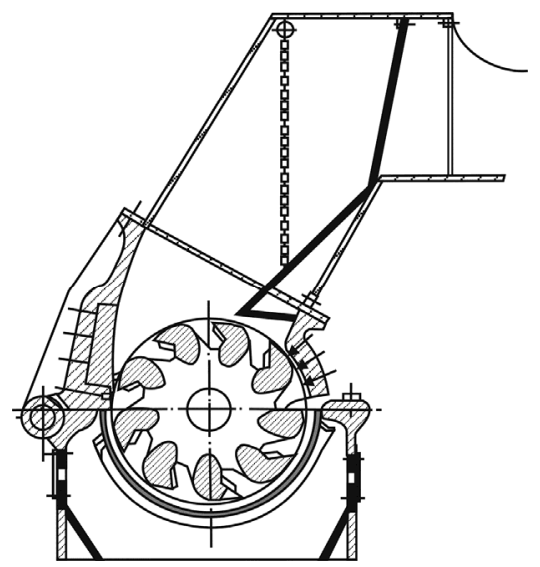

Rys. 6. The design of the mill manufactured by Alpine company, equipped with rotating cutters.
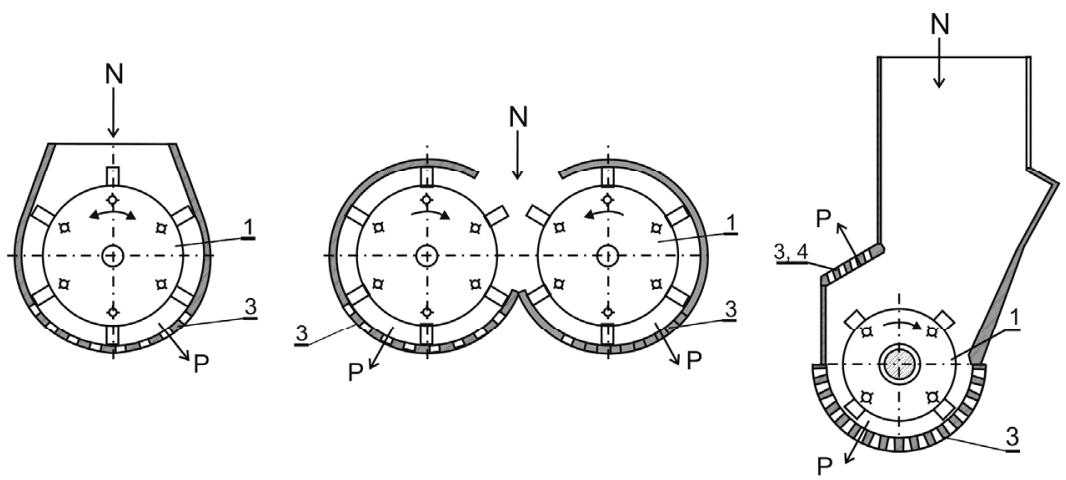

Fig. 7. Design solutions of mills with horizontal drive shaft: 1-rotor with rotating cutters, 2fixed cutters, 3-screens, 4 swinging parts of plates with holes playing the part of screens [46] 
Mills with horizontal drive shaft are equipped with disks with rotating and fixed parts and with screens spaced over the circumference (fig. 7).

An interesting design group is also constituted by mills in which the impact operation of elements spaced over the rotor circumference is used and which generate tangent stresses. The mill shown on the figure 8 can serve as the example of such a design solution.

An interesting design group is also constituted by mills in which impact operation of elements spaced over the rotor circumference is used and which generate tangent stresses. In the figure 8 can serve as the example of such a design solution.

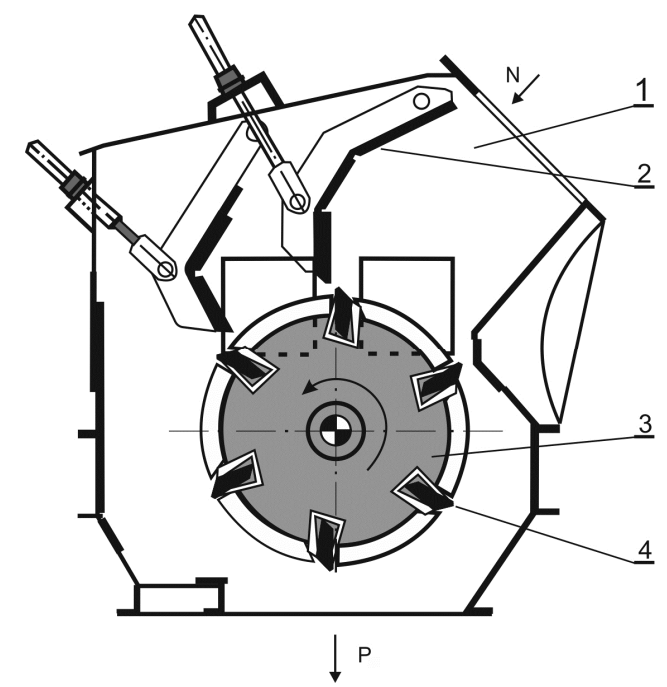

Fig. 8. View of the mill with beaters spaced over the rotor circumference, which also shear the material processed in the grinding chamber:

1-inlet of the fed material, 2-intensifying plates, 3-rotor, 4-beater.

Operating parameters of cutting mills depend on the number and layout of fixed and rotating cutters over the circumference as well as on the components intensifying the process (fig. 9).

The research works on new mill designs for vegetable and polymer materials has been conducted in the research and development centre of the City of Bydgoszcz (University of Technology and Life Sciences and Kazimierz Wielki University) for over 25 years. Among many design solutions developed there, it is worth to mention hyperboloidal mills invented by R. Konieczka [21, 22] and multi-edge mills developed and patented by J. Flizikowski and M. Bieliński [11]. The grinding process based on rotary cutting is used in knife mills that cut the material as a result of the cooperation between cutting edges of movable knives moving rotationally and fixed knives mounted on the mill housing. Fig. 10 shows a schematic diagram of a typical mill and its main parts.The grinding process based on rotary cutting is used in cutting mills equipped with hyperboloidal working chamber that cut the material as a result of the mating between cutting edges of rotating cutters moving rotationally, and fixed cutters mounted on the mill housing. 
a)

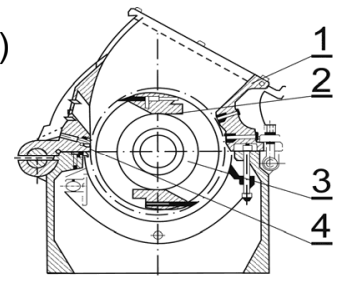

c)

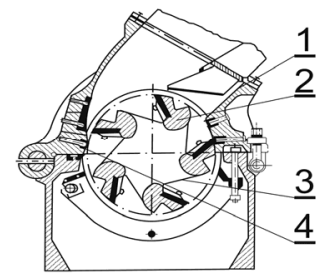

e)

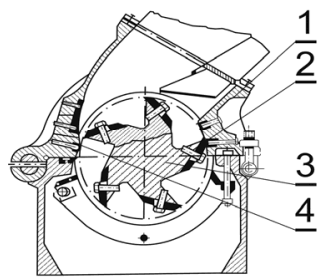

b)
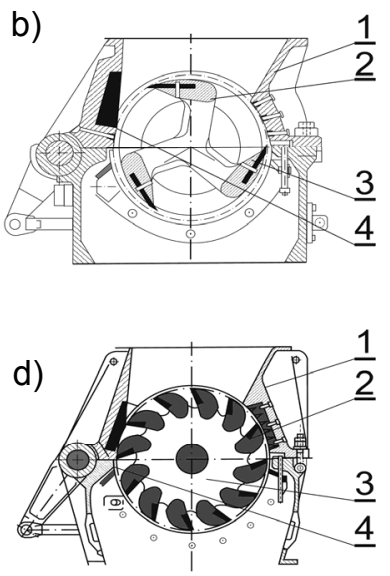

f)

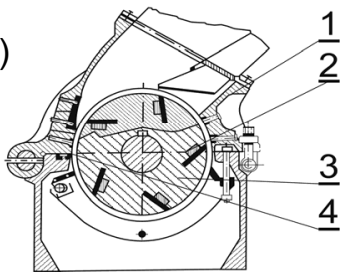

Fig. 9. Design solutions of cutting mills (based on the paper by M. Pahl) [35]:

a) with 2 rotating cutters and 1 fixed cutter, b) with 3 rotating cutters and 2 fixed cutters, c) with 5 rotating cutters spaced over the circumference and 2 fixed cutters, d) with 12 rotating cutters and 2 fixed cutters, e) with 5 rotating cutters and 2 fixed cutters, f) with milling cutters spaced over the circumference of the monolithic rotor and 2 fixed cutters; 1 - housing, 2 - rotating cutter, 3 - rotor, 4 - fixed cutter.

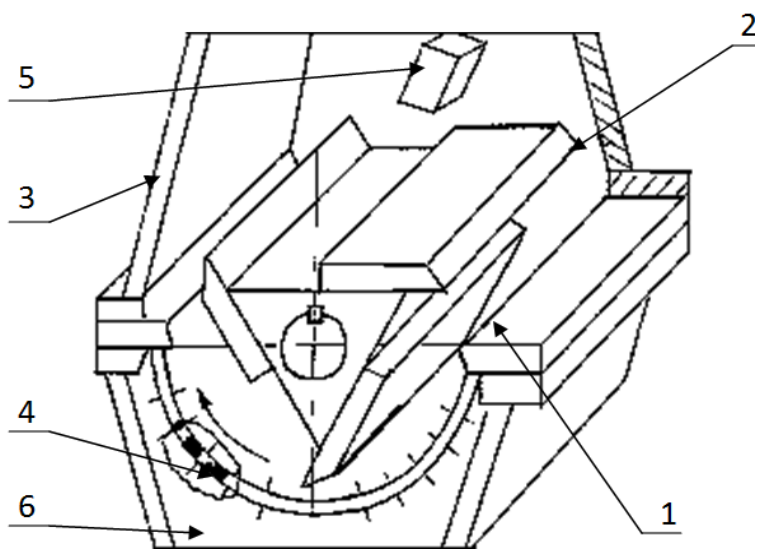

Fig. 10. Schematic diagram of a cutting mill [2, 8]: 1 - fixed knife, 2 - rotating knife, 3 - housing, 4 - sieve, 5 - fed material, 6 - product (elementary grain) [21] 
The essence of the multi-edge grinder operation (fig. 11) is that it consists of the set of working disks mounted coaxially on the shaft and the disks are provided with holes with grinding edges spaced over diameters increasing from the input to the output of the material from the grinding space, while the speed between the neighbouring disks is the grinding speed [12]. Multi-edge mills are members of the group of equipment, where the material is processed at the linear speed of the grinding edge of about $1 \mathrm{~m} / \mathrm{s}$ (fig. 5).

a)

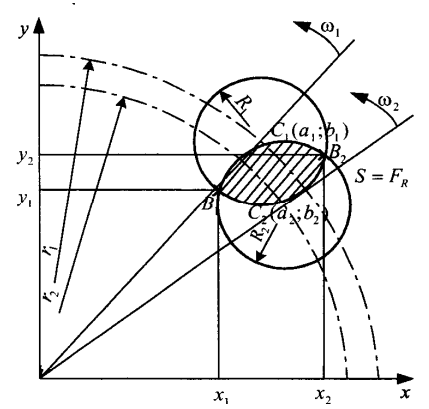

b)

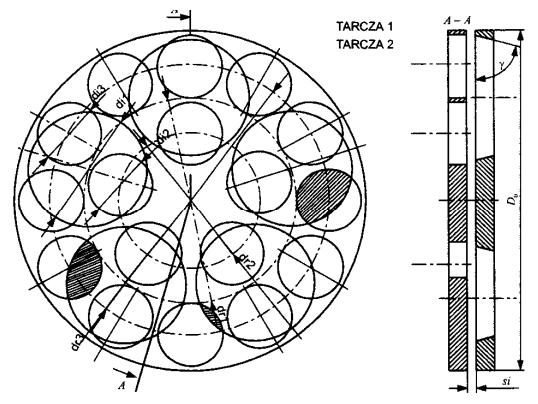

Fig. 11. The principle of the multi-edge grinder operation: a) geometric relationship between two holes of the neighbouring disks, b) view and section of two mating disks [13]

\section{Expected quality range of the comminution product: Dimensions and a shape of a granule, particle size distribution (PSD)}

Quality of comminution product is commonly assessed using screen analysis, i.e. by determining quantitative share of individual grain sizes in the sample of the polymer material using vibration of pneumatic screening through the set of analytic screens of specified rectangle mesh dimensions. The screen analysis is performed for grain size over $40 \mu \mathrm{m}$, because this is the minimum clearance of the screen mesh. The particle size distribution analysis for smaller grain is performed by sedimentation, which allows to separate grain of $1 \div 40 \mu \mathrm{m}$. Using optical and scanning microscope, it is possible to measure $0,6 \div 150 \mu \mathrm{m}$ grain.

Grain size is a very important issue in most of operations and processes. Each grain is characterized by such parameters like: length, width, height. For the process analysis purposes, the grain size is determined by relationship between dimensions at three axes: a, b, c (as a cuboid).

Apart from the size, also qualitative characteristics of the granulated product and its form are important. The ground product should be of regular, usually cylindrical or cubical shape,

R. Koch proposed more precise classification of the process as he assumed the following criterion: specific category of the ground product should include over $50 \%$ of the grain of specific size [20]:

$$
\begin{aligned}
& \text { - rough } \quad-0,5 \div 5 \mathrm{~mm} \text {, } \\
& \text { - medium - } 50 \div 500 \mathrm{~mm} \text {, } \\
& \text { - fine - } 5 \div 50 \mathrm{~mm} \text {, } \\
& \text { - colloidal - } \quad<5 \mathrm{~mm} \text {. }
\end{aligned}
$$


For process purposes, such as use of granular products obtained as a result of polymer and vegetable material grinding process, i.e. issues associated with their generation and future use, comparative indices are used. Those indices can be divided into the following three groups:

1. Physical indices characterizing geometric features and physical properties of the granular material include: grain sizes and shapes, grain collection distributions, size of control, outer upper or bottom particles as well as medium particles of specific weight percentage share of the control grain, specific surface area (kinetic), specific surface area (static), pycnometric density, micro-hardness, compressive strength, tensile strength, resistance to brittle fracture, hygroscopicity, adsorption and absorption properties, pyrophoric properties, colour, gloss, total volume of pores, average pore size and distribution, pore shape, internal friction angle, static and kinematical friction angle against metals etc.

2. Chemical indices specifying: content of the main component, content of the remaining components, content of impurities in individual phases (solid, liquid and gaseous), occurrence of oxide layers, corrosion resistance, chemical activity, electrochemical activity, catalytic properties, toxicity and other.

3. Process-related indices, including: degree of material size reduction (critical, medium, npercentage), area increase degree, grindability, susceptibility to agglomeration, water content, total efficiency, usable efficiency, unit energy demand, grinding process efficiency ratio, looseness, compactibility, compressibility, sinterability etc.

From the point of view of the granulated product user, other factors are also important, i.e. physical and chemical properties of the ground material, such as: crystal lattice structure of the material, fibrousnesses, isotropy or anisotropy, plasticity, content of gases inside grains and gases absorbed over the grain surface, reactivity, adsorptivity, type and number of lattice defects, micro-structure, grain surface condition.

Granulated material quality indices depend on the type of the original material and planned use of the granulated material. Thus completely different quality indices are used for: polymer materials, (repeated recycling, fillers, dyes, fibres, seals, insulations etc,), fuels (combustion in power generation boilers, gasification, conversion into liquid fuel), cosmetics, ceramic bio-materials, metals, composites, brittle plastic and other materials.

\section{Grinding process research methods}

Taking into account useful form of the resulting product and the need for the analysis of high energy-consuming stages of the recycling process, it seems purposeful to develop research methods of the grinding engineering. Several thousands attempts to formally define the following aspects of the grinding process have been made for the last one hundred and fifty years, phenomena, system, relationships, design and the process itself [ 2 , $6,7,16,23,38,44,47]$. The main aim of the research works is to improve the general mathematical description and to help grinding equipment researchers and designers to increase the equipment efficiency: to reduce energy demand of comminution process and of drives, to increase efficiency and the quality of the grinder design, the charge and the grinding product (the function, grain size distribution parameters and the specific surface). There are many comminution hypotheses, but they can be categorized in three groups [10, 13]: 


\begin{tabular}{|l|l|l|}
\hline \multicolumn{1}{|c|}{ 1. classic } & \multicolumn{1}{|c|}{2.} & \multicolumn{1}{|c|}{3.} \\
\hline $\begin{array}{l}\text { associated with mechanics of the } \\
\text { charge grinding process and } \\
\text { relationships between results of } \\
\text { the grinding process, such as: } \\
\text { properties and energy demand } \\
\text { of the charge deformation }\end{array}$ & $\begin{array}{l}\text { associated with relationships } \\
\text { materials and the standards } \\
\text { (relating mainly to grain size }\end{array}$ & $\begin{array}{l}\text { describing } \\
\text { thermodynamic } \\
\text { aspects of the grinding } \\
\text { processes }\end{array}$ \\
\hline
\end{tabular}

The only hypotheses that have been applied in practice were those of the first group, i.e. associated with the energy of the deformation, i.e. symptoms of grindability, good proportions between the type, form parameters and grain size distribution of the charge and the product as well as the energy demand.

Mechanical engineering and machine operation methodology in recycling and issues associated with the properties of the charge and the grinding product are subject of many studies in Poland and abroad. Some of them indicate to similarity to the problems relating to material removal processes. Those studies allow energy demand analysis in those processes (e.g. machining), so that selection of less energy consuming variant is possible [1, 8, 33, 37].

Unit grinding, cracking, load distribution issues etc. are also important for better understanding of the grinding process (fig. 2.3) [36]. Studies in that field are performed, among others, at the University of Sheffield [41].

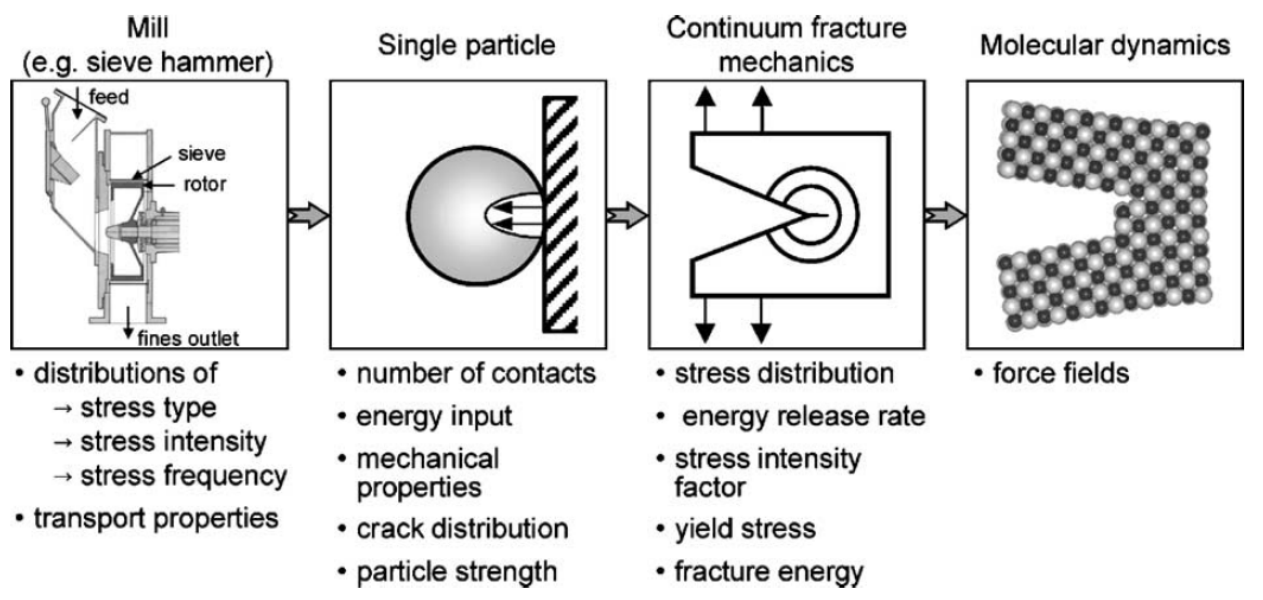

Fig. 12. The scope of research on grinding process [36]

\section{Own research method of multi-edge grinding}

Studies on the innovative design of multi-edge mills using author's own method are based on geometric relationships of the multi-edge mill for granulated and chunked materials patented in 1989 [11]. The multi-edge unit is a set of disks or drums with holes spaced over coaxial perimeters. Thanks to proper geometry of holes in their disks, drums or strips as well as due to appropriate relationship of the movement between neighbouring edges, multi-edge grinders are able to grind plastic using the neighbouring edges (fig. 13) [28]. 
a)

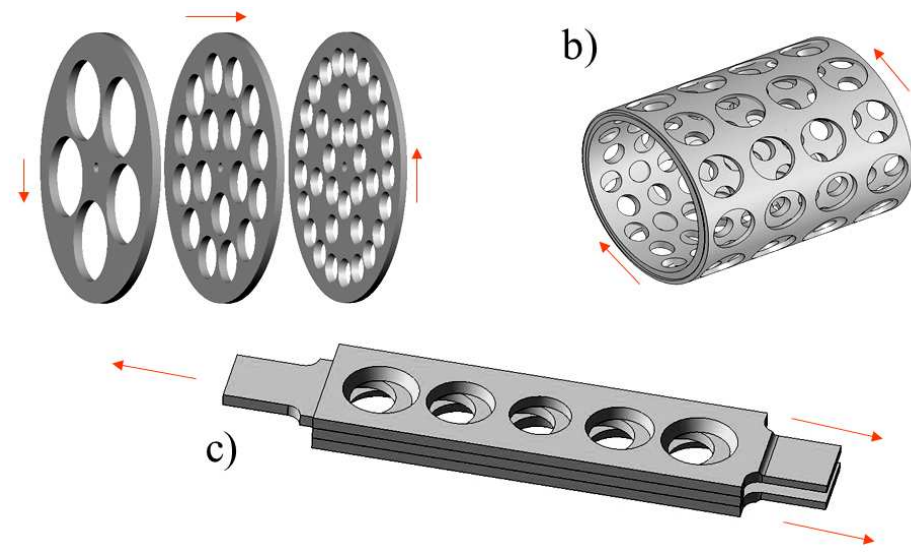

Fig. 13. Possible design implementatios of the disks - a), drums - b) and perforated plates c)

Design solutions - from the allowable collection (1), (2) - that maximize or minimize values of selected operational characteristics were assumed as the general model of multi-edge grinding studies. The usability conditions are met by design features that maximize the function of: energy efficiency, overall efficiency, capacity, material size reduction degree for:

$$
\left\{C_{k}^{*} \in \phi\right\}:\left\{\underset{c_{k} \in \phi}{\wedge} H_{u}\left(c_{k}\right)<H_{u}\left(c_{k}^{*}\right)\right\} \text { for: } H_{u,}: e_{R} \uparrow, W_{u} \uparrow, \eta_{\rho} \uparrow, \lambda \uparrow
$$

While minimization of the power demand, unit energy consumption, energy dissipation, torque, angular, linear and rotational speed - as the measure of usability - can be achieved for effective design features:

$$
\left\{C_{k}^{*} \in \phi\right\}:\left\{\underset{c_{k} \in \phi}{\wedge} H_{u}\left(c_{k}\right)>H_{u}\left(c_{k}^{*}\right)\right\} \text { for: } H_{u}: N_{v} \downarrow, E_{T} \downarrow, M_{\chi} \downarrow, \omega \downarrow, \varpi \downarrow, v \downarrow
$$

where:

$C_{k}^{*} \quad$ - the solution to the problem,

$\phi \quad$ - allowable space of the design features vector $C_{k}^{*}$,

$H_{u} \quad$ - operational characteristics,

$e_{R} \quad$ - energy efficiency function, - ,

$W_{\mathrm{u}}$ - mass capacity of the process, $\mathrm{kg} / \mathrm{h}$,

$P_{e} \quad$ - power demand, $\mathrm{kW}$,

$E_{T} \quad$ - unit energy demand, $\mathrm{J} / \mathrm{g}$,

$\lambda$ - break-up degree (product dimensions), $\mathrm{mm}$,

$M_{c} \quad$ - torques, $\mathrm{N} \cdot \mathrm{m}$,

$\omega, n, v$ - angular, rotational, linear speeds, $\mathrm{rad} / \mathrm{s}, 1 / \mathrm{s}, \mathrm{m} / \mathrm{s}$,

$\eta_{\rho} \quad$ - grinding efficiency, -

The objectives of the study were fulfilled thanks to: 
- assessment of the impact of material properties and the form of the sample on the function of forces and quasi-shear labour,

- the analysis of the impact of the disintegrating elements speed on the value of quasishear labour,

- determining the impact of the hole edge angle on the value of quasi-shear labour,

- implementation of the mechanisms of simulation research on quasi-shear resistance and sections for selected variants,

- $\quad$ assessment of the grinding process operational characteristics in physical conditions.

\subsection{Description of a laboratory set-up of comminution, measure - possibilities}

In this research, basic characteristics of a selected multi-edge grinding type were verified in laboratory set-up. These include: energy demand for the process, torques and output. Stress values were determined using mathematic relationships describing the area of grinding, taking into account design features of the grinding unit [14]:

$$
2 A_{r}=\frac{6,11}{\rho \cdot s_{i}}\left(\left(0,043 \cdot s_{i}\right)^{-1,12 D_{o i}+1,18}\right) \cdot v_{r} \cdot e^{1,88 \cdot n_{w}^{2}}
$$

where:

$A_{r} \quad$ - the area of grinding, $\mathrm{mm}^{2}$,

$\rho \quad$ - density of materials subject to grinding, $\mathrm{g} / \mathrm{cm}^{3}$,

$s_{i} \quad-$ the index of the gap between disks (drums) of the grinder, (-),

$D_{o i} \quad$ - diameter indicator of the i-th disk (drum) provided with holes, (-),

$n_{w} \quad$-the factor dependent on the type of processed materials; $\mathrm{n}=0,75 \div 1,00$,

$v_{r} \quad-$ relative speed between quasi-shearing edges, $\mathrm{m} / \mathrm{s}$.

The author performed laboratory research on multi-edge grinding for two design versions of the grinding unit, chosen based on the matrix of possible solutions [27], meeting preliminary criteria as regards energy efficiency and the grain size curve [14]: i.e. one of the drum and the disk version, provided with polygonal openings (fig. 14).

\subsubsection{Description of a laboratory station}

The laboratory station was built according to the author's own concept as part of KBN (State Committee for Scientific Research) Research project performed in the years 2003-2005 [25], and then adapted to the purposes of grinding energy efficiency research as part of the MNiSW (the Ministry of Science and Higher Education) project [24] (fig. 15, 16). The frame and the drive were prepared to allow measurement of torques and angular speeds at any position of the drive shaft (from the vertical to the horizontal one). The proposed design of the station ensures that the drive system, together with the measuring sensors, is an integral base for research using different disintegrating (grinding) units. The shaft end with working systems of the grinder fixed to it are used for that purpose. This ensures that the measuring parameters are unchanged and guarantees possibility to assess the energy input needed to grind unit mass (volume) of the material using different configurations (disintegration methods). Research can be performed with stepless control of the motor rotational speed in the range $0 \div 2900 \mathrm{rpm}$. 


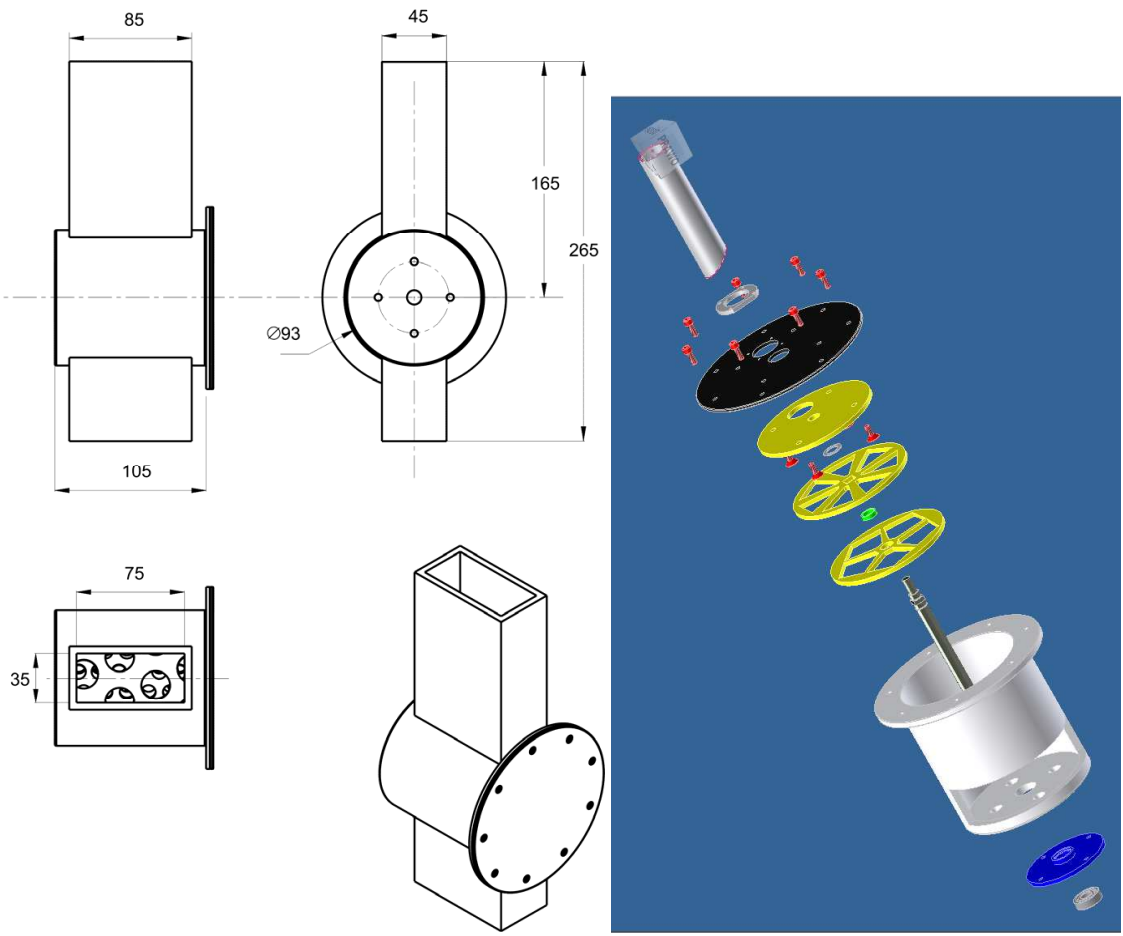

Fig. 14. The multi-edge grinder unit: a) drum type - orthogonal projection and axonometric view of the housing, b) disk type - exploded view

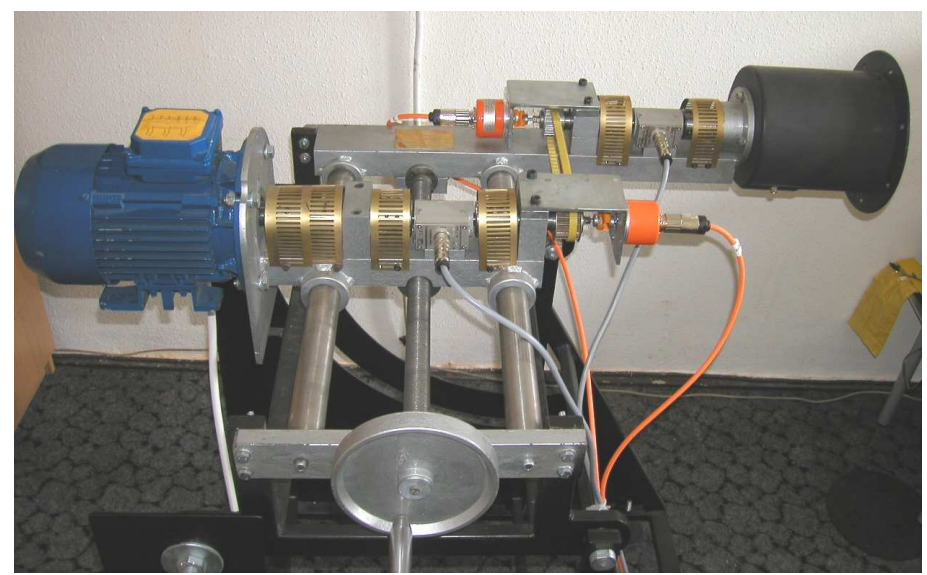

Fig. 15. The station of the general-purpose laboratory grinder ULR-2,0/2004 - with horizontal position of the drive shaft

Figure no. 16. shows mechanical diagram of the station of the all-purpose laboratory grinder ULR-2,0/2004. 


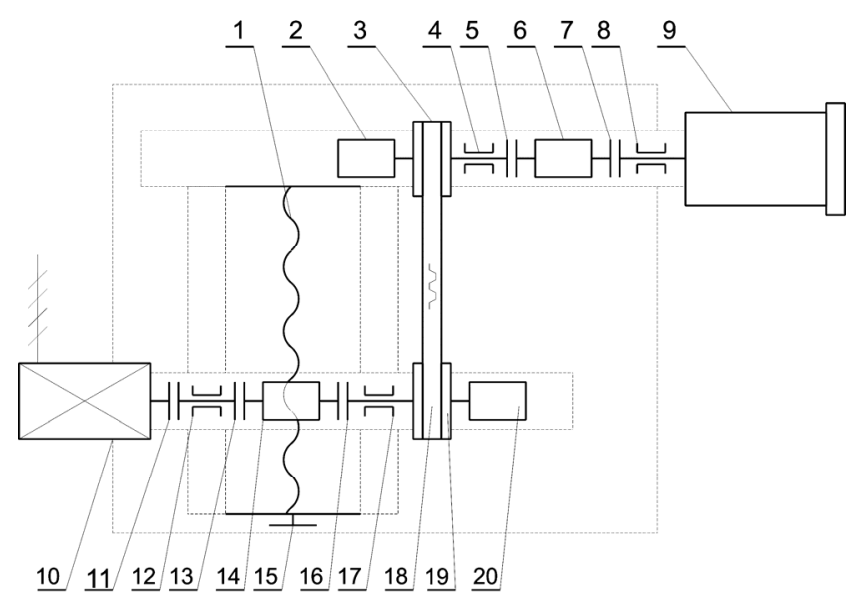

Fig. 16. Mechanical diagram of the station of the all-purpose laboratory grinder ULR-2,0/2004: 1 - the screw for adjustment of the distance between the motor shaft and the grinder shaft, 2 - rotary-pulse transducer, 3 - the pulley of the toothed belt transmission, 4 - journal bearing, 5 - clamp coupling, 6 - torque meter, 7 - clamp coupling, 8 - journal bearing, 9 - grinder chamber, 10 - motor, 11 - clamp coupling, 12 - journal bearing, 13 - clamp coupling, 15 - torque meter, 16 - clamp coupling, 17 - journal bearing, 18 - toothed belt of the transmission, 19 - the pulley of the toothed belt transmission, 20 - rotary-pulse transducer

Output signals from the torque meter are recorded using a 4 - channel measurement amplifier Spider 8 manufactured by HBM, while the study results were processed using the software CATMAN developed by HBM. Electric power was measured using the generalpurpose power meter Hioki 3169 - 20/21 with the software (power measurement support software) Hioki 9625.

\subsection{Results: Energy consumption for chosen modes of grinding, influence of design features on the process and the quality of grinding product}

The study examined the energy and torque demand for different design versions of the grinders for processing polymer recyclates (fig. 17).

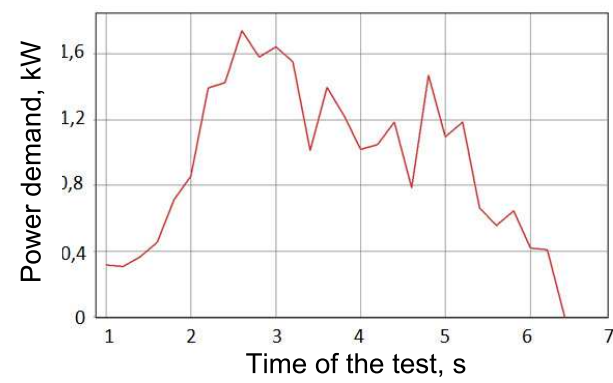

(a)

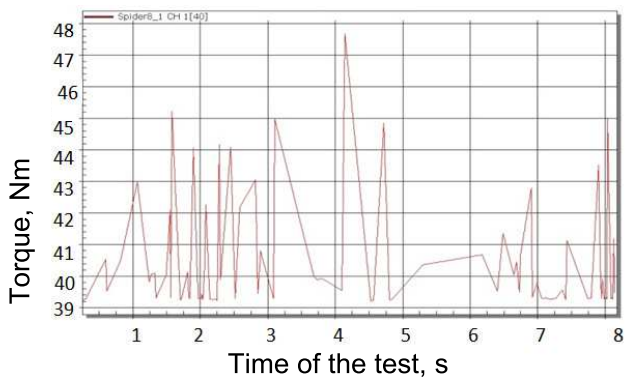

(b)

Fig. 17. Sample results of laboratory comminution tests: a) power demand - the drum mill, b) torque - the drum mill 


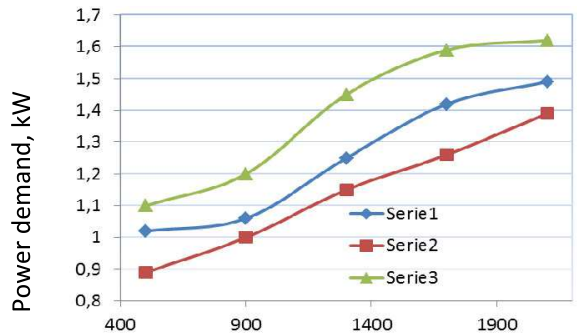

Rotational speed, rpm

(a)

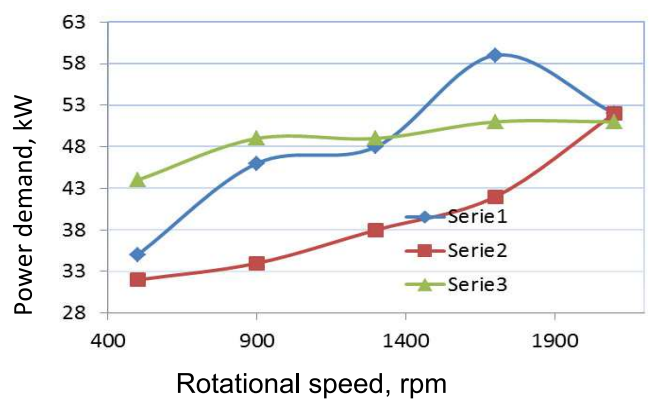

(b)

Fig. 18. Influence of the rotational speed on the power demand during PP grinding process - a) Influence of the rotational speed on the torque value - b), series 1 - the disk mill with cylindrical holes, series 2 - the disk mill with polygon holes, series 3 - the drum mill

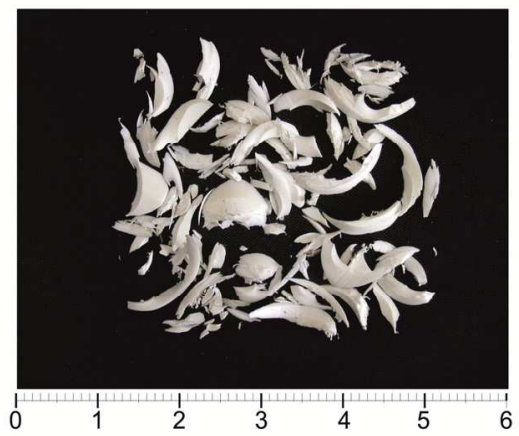

(a)

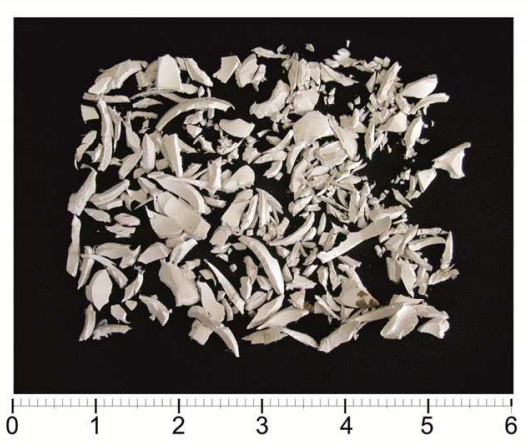

(a)

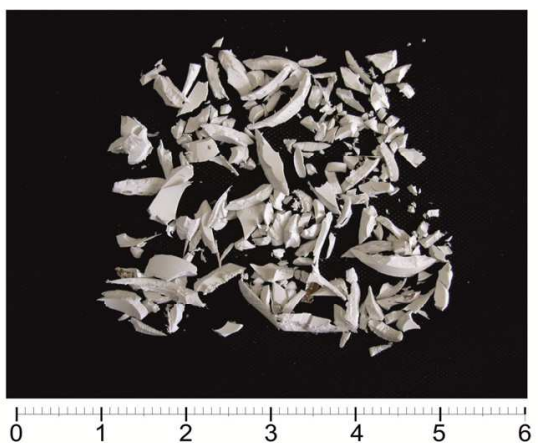

(b)

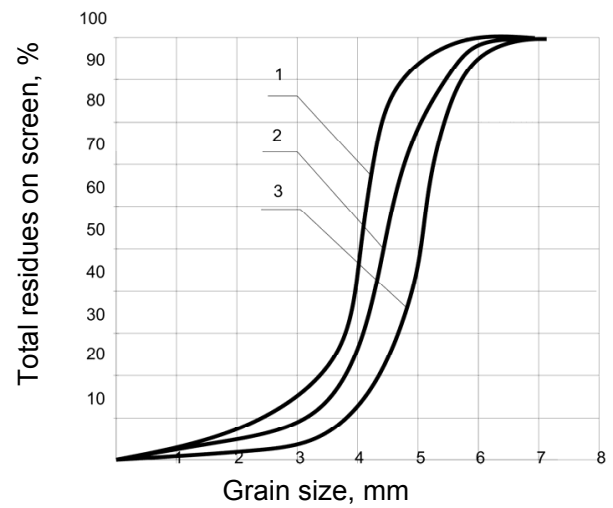

(b)

Fig. 19. PVC obtained as a product of grinding using a disk mill with cylindrical holes at three different rotational speeds: a) $500 \mathrm{rpm}$, b) $1300 \mathrm{rpm}$, c) $2100 \mathrm{rpm}$, d) product grain size distribution curve: 1 - $500 \mathrm{rpm}, 2$ - $1300 \mathrm{rpm}, 3$ - $2100 \mathrm{rpm}$ 
Power demand and torque demand diagrams as the function of the rotational speed were prepared based on the average values of the obtained results (fig. 18).

The grinding product was assessed by means of the sieve analysis, performed using the vibration screen AS 200 basic manufactured by RETSCH (fig. 19). The product grain size distribution curve before the expected further processing ranges from 2 to $6 \mathrm{~mm}$. With such range the product is classified as suitable for further processing.

\subsection{New methods which open variety of new grinding research opportunities (CAD/CAE and $\mathrm{Al}$ - genetic algorithms)}

\subsubsection{Computer simulations of multi-edge grinding}

Computer simulations are currently a necessary tool of machine and equipment design. Using those new technologies, it is possible to build virtual design models allowing efficient preparation of the drawing documentation and implementation of computer simulations (CAD/CAE). The purpose of grinding simulation results and analysis is to outline the range of design features for which assumed criteria are met. The application SolidWorks Motion is used to perform strength and kinematic simulations using virtual models. With the application it is also possible to verify future correct operation of the system at the prototype stage.

Grinding simulations were performed for two types of the general-purpose laboratory grinder ULR-2,0/2004: the drum and the disk one (fig. 20), and the load and stress simulations during single grinding were performed using the application SolidWorks Simulation.

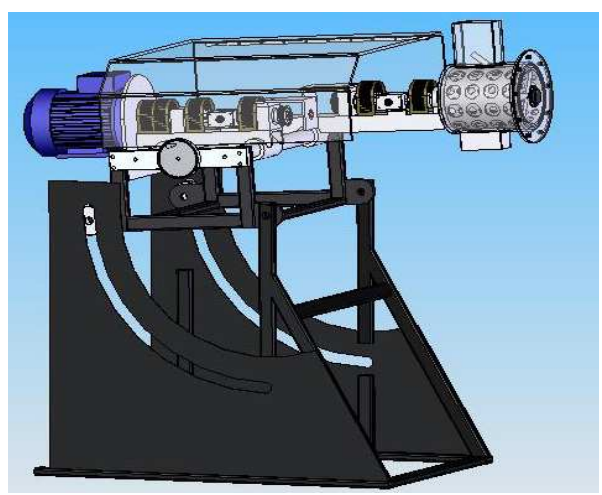

(a)
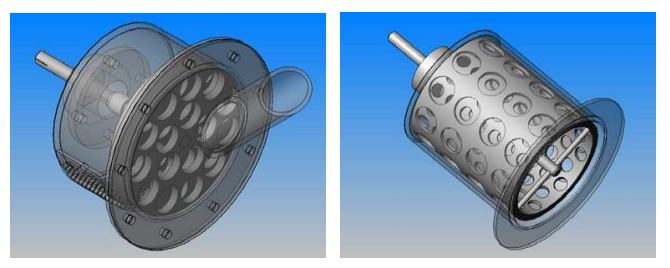

(b) (c)

Fig. 20. Laboratory mill ULR-2,0/2004 designed in SolidWorks environment: a) general view, b) disk unit, c) drum unit.

As a result of simulation using SolidWorks Motion, it has bee determined that the value of the contact force and stress for both types of the grinder working units rises with the growth of the rotational speed within the range of $52,82 \div 203,02 \mathrm{MPa}$ (for the drum type system) and $46,47 \div 142,40 \mathrm{MPa}$ (for the disk type system). 


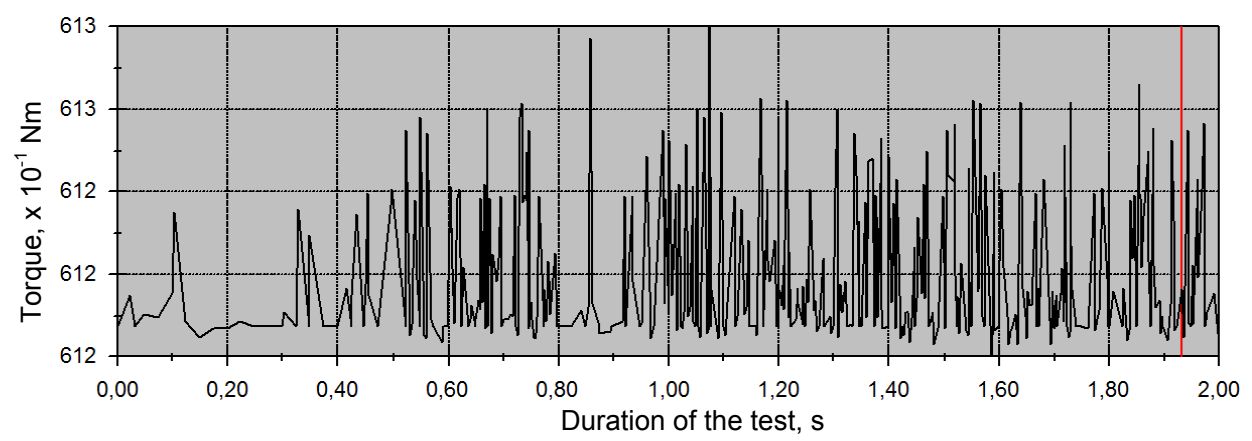

Fig. 21. Simulation of the torque function during grinding of PVC samples using the drum mill (SolidWorks Simulation).

Optimum design solutions of grinding disks and drums were found by implementation of genetic algorithms. The starting point in that method are design features of the grinder base disk. Figure no. 22 shows four consecutive stages of processing for the same disk (using the application tAG_Project1) [26].
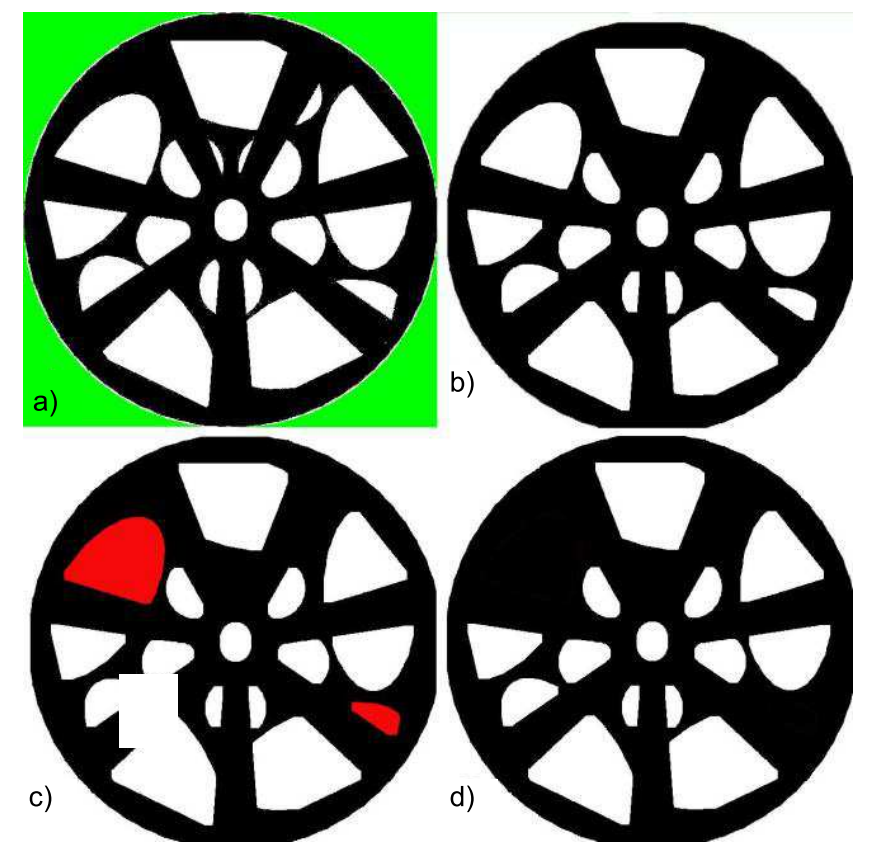

Fig. 22. Consecutive stages of the grinder disk modification: a) result of the crossing, b) the disk after morphologic optimisation, c) mutation phase, d) final result of the disk optimisation.

Based on geometric analysis performed using CAD applications, disks with the following hole geometry and layout were proposed (fig. 23): 

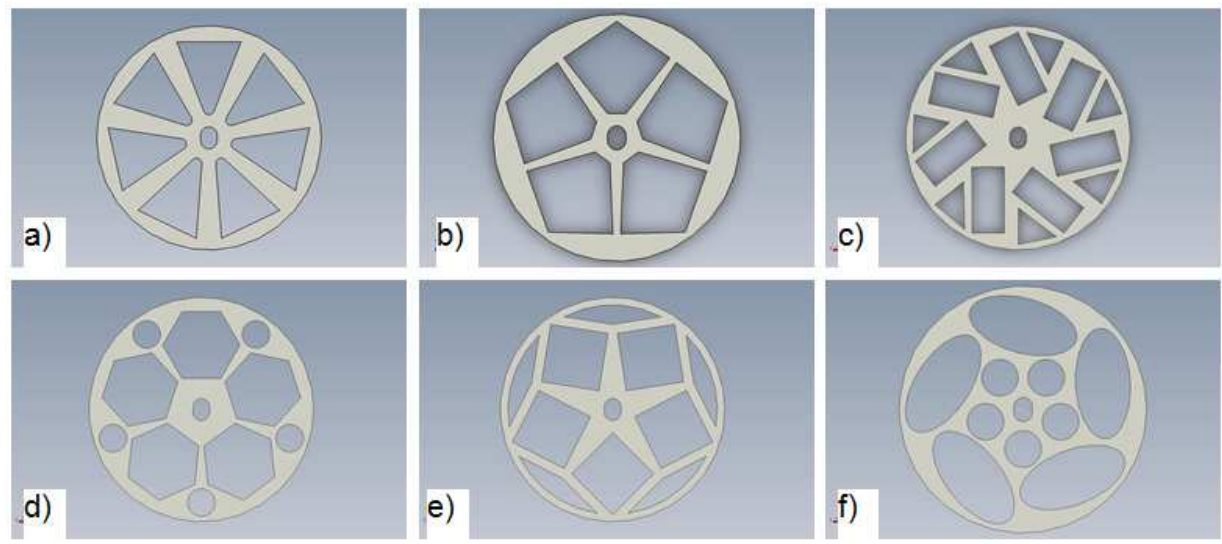

Fig. 23. Chosen disk design solutions as the area of design feature selection. a) the disk triangular holes, b) pentagonal holes, c) rectangular and triangular holes, d) hexagonal and cylindrical holes. e) quadrangular and triangular holes, f) circular and elliptical holes

\subsection{Analysis of results}

The following basic characteristics were verified in the study: energy demand for the grinding process, torque function and the efficiency. Laboratory tests of the multi-edge grinder were performed for three design versions of the grinding units: i.e. the drum and the disk version, provided with cylindrical and polygonal holes. The rotational speed values were included within the range $(500 \div 2100) \mathrm{rpm}$. The study shows that the most advantageous solution as regards minimum power demand is the disk grinder with disk provided with polygonal holes. On average, it ensures $10 \div 15 \%$ lower grinding power demand compared to the disk grinder with cylindrical holes and about $15 \div 20 \%$ lower power demand compared to the drum mill. The average power demand ranges from 1 to 1,8 $\mathrm{kW}$ and the average torque value is included in the range $35 \div 60 \mathrm{Nm}$.

Power consumption for grinding of one mass unit to the size suitable for further processing was estimated on that base. In case of the drum unit, the power demand was 0,042 $\mathrm{kWh} / \mathrm{kg}$, while for the disk unit: $0,056 \mathrm{kWh} / \mathrm{kg}$.

\section{Conclusions and future work}

It can be assumed that research works to improve grinder designs shall continue. This results from the necessity to reduce size of different materials characterized by wide scope of material properties. Thanks to introduction of innovative multi-edge grinder designs, original research procedures led to design and construction of high-grinding efficiency test station. With such test stations, it is possible to continue promotion of highly innovative grinding solutions. Genetic algorithms were successfully used to design the grinder disks and shapes and sizes of disk holes. Using modern technologies, it is possible to machine holes even of very complex shape in disks and drums.

The methodology of selecting multi-edge grinders for polymer materials processing includes state-of-the art IT tools, A general grinding database was built and developed 
using that methodology and it continues to be developed based on the backbone expert system. The highest usability within the research scope of the cutting hole edge angle $(\beta=$ $\left.60^{\circ}, 75^{\circ}, 90^{\circ}, 105^{\circ}, 120^{\circ}\right)$ was achieved for $\beta=60^{\circ}$ ( $2^{\text {nd }}$ grade non-linear regression equations $L$ $=\mathrm{f}(\mathrm{b})$. While minimum usability of quasi-shear labour was obtained for the angle $\beta=90^{\circ}$ (samples with outer diameters $D_{z} \geq 0,5 d_{\text {otw. }}$ ) and for the angle $\beta=120$ o for samples with outer diameters of $\mathrm{D}_{\mathrm{z}} \leq 0,5 \mathrm{~d}_{\mathrm{otw}}$.

The precondition for further development of methods for selection of recycling-related grinding types is preparation of detailed mathematical models, improvement of recyclates recycling technologies and, as a result, manufacturing of recycled products that are characterised by quality level acceptable for further processing.

Recyclates with the average diameter of $D_{z}<50 \mathrm{~mm}$ and wall thickness of $\mathrm{g}<6 \mathrm{~mm}$ which are planned to be ground using the grinder with three disks or drums should be processed using the machine equipped with minimum $5 \mathrm{~kW}$ electric drive motor and the transmission gear capable to reduce linear speed of the grinder edge to $0,5 \mathrm{~ms}^{-1}$.

\section{Acknowledgments}

This work was financially supported by the Polish Ministry of Science and Higher Education

\section{References}

[1] Austin L.G., Klimpel R.R.: The theory of grinding operations. Ind. Eng. Chem. 56, p. 18-29 (1964).

[2] Austin L.G.: Introduction to the mathematical description of grinding as a rate process. Powder Technology, 5, p. 1-17 (1971-1972)

[3] Bauer W.: Untersuchung des Einzelzerkleinerungsvorganges in Schneidmühlen am Beispiel von Polypropylen. Reihe 3 - Verfahrenstechnik, Nr. 694. VDI Verlag, Düsseldorf 2001

[4] Bielinski M.: Materiałowa i przetwórcza charakterystyka wybranych tworzyw wtórnych. Rozprawy $n r$ 84, Publishing House of ATR in Bydgoszcz 1998

[5] Błędzki A. K. (editing): Recykling materiałów polimerowych. WNT, Warsaw 1997

[6] Brożek M., Mączka W., Tumidajski T.: Modele matematyczne procesów rozdrabniania, Wydawnictwa AGH Kraków, 1995

[7] Butzen, G. A., Adams, G. A.: Size Reduction/Granulating. Van Nostrand Reinhold Co., Injection Molding Handbook, 1986

[8] Darlewski J., Gawlik J., Grzesik W., Jemielniak K., Ruszaj A., Weiss E., Zebrowski H.: Trendy w ubytkowych metodach obróbki, Automatyzacja produkcji '97 Innowacje w technice i zarzadzaniu, Wrocław 1997, Scientific research works at the Institute of the Machine Engineering, Automation and Robotics of Wrocław University of Technology, no. 67, Conference series no. 29, volume 1, 175-212

[9] Dmitrewski J.: Teoria i konstrukcja maszyn rolniczych. T.3, PWRiL, Warszawa 1978

[10] Drzymała Z. (et al.): Badania i podstawy konstrukcji młynów specjalnych. PWN. Warszawa, 1992.

[11] Flizikowski J., Bielinski M.: Rozdrabniacz wielotarczowy zwłaszcza do materiałów ziarnistych i kawałkowych. Polish patent, P - 144566, UP Warsaw 1989 
[12] Flizikowski J.: Badania i podstawy konstrukcyjne rozdrabniaczy wielotarczowych. Rozprawy ATR no. 42, WMN - ATR Bydgoszcz 1990

[13] Flizikowski J.: Rozdrabnianie tworzyw sztucznych. WMN - ATR Bydgoszcz, 1998

[14] Flizikowski J.: Sprawozdania z badań. Grant (KBN)MNiI, PB 622/T08/2002, AGH Kraków - ATR Bydgoszcz, 2002-2005

[15] Flizikowski J. : Micro- and Nano-energy Grinding. ISBN-10 9814303534. Pan Stanford Publishing. 2011

[16] Giersemehl, M., G. Plihal: Fine Grinding System with Impact Classifier Mill and Cyclone Classifier. Company Affiliation: Neuman \& Esser GmbH Mahl- und Sichtsysteme Published in Journal: powder handling \& processing Year: 1999 Volume: 11 Number: 3 Page: 269

[17] Höffl K.: Zerkleinerungs und Klassiermaschinen. Springer-Verlag, Berlin 1986

[18] http://www.plasticseurope.org/documents/document/20101028135906final_plasticsthefacts_26102010_lr.pdf (December 2010)

[19] Kalman H., Hubert M., Grant E., Petukhov Y., Haim M.: Fatigue behaviour of impact comminution and attrition units. Powder Technology 146, 2004

[20] Koch R., Noworyta A.: Procesy mechaniczne w inżynierii chemicznej. WNT, Warsaw 1998

[21] Konieczka R.: Podstawy mechanicznych procesów recyrkulacji folii z polietylenu małej gęstości. Rozprawy ATR no. 74, Bydgoszcz 1996

[22] Konieczka R.: Urządzenie rozdrabniające. Polish patent no. 130061, UP Warsaw 1987

[23] Lowrison G. Ch.: Crushing and grinding. Verlag Butterworth, London, 1974

[24] Macko M.: Badania procesu rozdrabniania tworzyw polimerowych i materiałów biologicznych w kierunku podwyższenia efektywności energetycznej - MNiSW research project no. N N508 440536 (2009-2011)

[25] Macko M.: Tworzywowo zintegrowane podstawy inteligentnego rozdrabniania i granulowania w recyklingu - KBN research project (MNiI) no. 978/T08/2003/24 (2003-2005)

[26] Macko M., Czerniak J.: The evolutionary method for optimising disk design of multiedge grinders. Journal of Theoretical and Applied Mechanics - the paper accepted for publishing in 2012.

[27] Macko M.: Metodyka badao procesu rozdrabniania wielokrawędziowego w recyklingu. Inżynieria i Aparatura Chemiczna, Gliwice, 3/2005, p. 51-52

[28] Macko M.: Wpływ cech konstrukcyjnych zespołu wielotarczowego na charakterystyki użytkowe procesu rozdrabniania rurowych recyklatów tworzyw sztucznych. Thesis. WM-ATR, Bydgoszcz 2000

[29] Marsh G.: Facing up to the recycling challenge, Reinforced Plastics, Vol. 45, Issue 6 (2001), p. 22-26

[30] N. N.: Doppelrotor-Shredder. Prospektmaterial, Fa. Hoger Maschinenbau GmbH \& Co. KG, Bergkirchen

[31] N. N.: Rotorscheren Typ S, Typ I. Prospektmaterial, Fa. Societe Industrielle de la Doux SA, Saint-Sulpice (Schweiz), 2001

[32] N. N.: Universal-Zerkleinerer ZU. Alpine Aktuell Nr. 14, Prospektmaterial, Fa. Alpine AG, Augsburg

[33] Osman M.O.M., Mueller G.S.: Reference systems for cutting tool geometry and their transformation matrices. Int. J. Prod. Res. 1973, vol.11, nr 2, p. 113-124 
[34] Pahl M. H.: Zerkleinerungstechnik. Praxiswissen Verfahrenstechnik. Mechanische Verfahrenstechnik: Auflage, Leipzig, 1993

[35] Pahl. M. H.: Zerkleinerungstechnik. Verlag TÜV, Rheinland 1994

[36] Peukert W.: Material properties in fine grinding. Int. J. Miner. Process. 74S (2004) p.3-17

[37] Pienkowski G.: Ocena energochłonności operacji obróbki ubytkowej. Thesis, Wrocław University of Technology, 2006

[38] Prasher C.L.: Crushing and Grinding Process Handbook. Verlag Wiley \& Son, Chichester, 1987

[39] Repelin V., Govin A., Rolland M., Guyonnet R.: Energy requirement for fine grinding of torrefied wood. Biomass \& Energy 34 (2010) p. 923-930

[40] Rumpf H.: Die Einzelkornzerkleinerung als Grundlage einer technischen Zerkleinerungswissenschaft. Chemie Ingenieur Technik 37, No.. 3/1965, p. 187-202

[41] Salman A.D., Biggs C.A., Fu J., Angyal I., Szabo M., Hounslow M.J.: An experimental investigation of particle fragmentation using single particle impact studies. Powder Technology, Volume 128, Number 1, 4 December 2002, p. 36-46

[42] Schubert G., Bernotat S.: Comminution of non-brittle materials. Int. J. Miner. Process., $74 S$ (2004), p. 19-30

[43] Sidor J.: Badania, modele i metody projektowania młynów wibracyjnych. Rozprawy 150. AGH Publishing House, Kraków 2005

[44] Siwiec A.: Związek pomiędzy opisem procesu rozdrabniania procesami Markowa a hipotezą Rittingera. Górnictwo. 1999 z. 4 (p. 237 - 244)

[45] Wang Y., Forssberg E.: Enhancement of energy efficiency for mechanical production of fine and ultra-fine particles in comminution. China Particuology 5 (2007), p. 193-201

[46] Woldt D., Schubert G., Jackel H.-G.: Size reduction by means of low-speed rotary shears. Int. J. Miner Process. 74S (2004) S405-S415

[47] Zawada J.: Wstęp do mechaniki procesów kruszenia. ITEE Radom, 1998

[48] Zimniak J., Konieczka R.: Zerkleinerungs- und Mischprozesse für Verbundwerkstoffe. $X V$. Fachtagung über Verarbeitung und Anwendungen von Polymeren TECHNOMER'97, November 1997, Chemnitz P36, p. 1- 8 


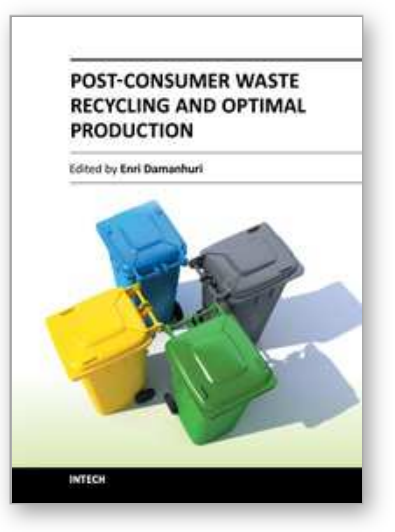

\author{
Post-Consumer Waste Recycling and Optimal Production \\ Edited by Prof. Enri Damanhuri
}

ISBN 978-953-51-0632-6

Hard cover, 294 pages

Publisher InTech

Published online 23, May, 2012

Published in print edition May, 2012

This book deals with several aspects of waste material recycling. It is divided into three sections. The first section explains the roles of stakeholders, both informal and formal sectors, in post-consumer waste activities. It also discusses waste collection programs for recycling. The second section discusses the analysis tools for recycling system. The third section focuses on the recycling process and optimal production. I hope that this book will convey both the need and means for recycling and resource conservation activities to a wide readership, at both academician and professional level, and contribute to the creation of a sound materialcycle society.

\title{
How to reference
}

In order to correctly reference this scholarly work, feel free to copy and paste the following:

Marek Macko (2012). Size Reduction by Grinding as an Important Stage in Recycling, Post-Consumer Waste Recycling and Optimal Production, Prof. Enri Damanhuri (Ed.), ISBN: 978-953-51-0632-6, InTech, Available from: http://www.intechopen.com/books/post-consumer-waste-recycling-and-optimal-production/comminutionas-an-important-stage-in-recycling

\section{INTECH}

open science | open minds

\section{InTech Europe}

University Campus STeP Ri Slavka Krautzeka 83/A 51000 Rijeka, Croatia Phone: +385 (51) 770447

Fax: +385 (51) 686166 www.intechopen.com

\section{InTech China}

Unit 405, Office Block, Hotel Equatorial Shanghai No.65, Yan An Road (West), Shanghai, 200040, China 中国上海市延安西路65号上海国际贵都大饭店办公楼405单元 Phone: +86-21-62489820

Fax: +86-21-62489821 
(C) 2012 The Author(s). Licensee IntechOpen. This is an open access article distributed under the terms of the Creative Commons Attribution 3.0 License, which permits unrestricted use, distribution, and reproduction in any medium, provided the original work is properly cited. 